\title{
John Haught on original sin: A conversation
}

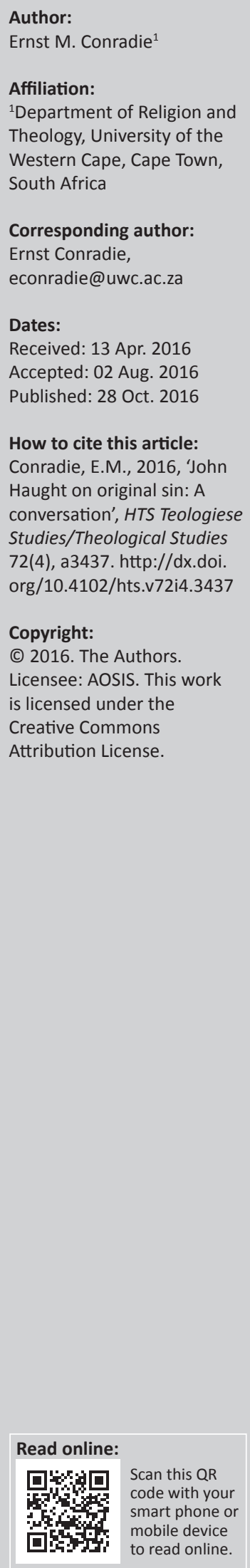

This article engages with John Haught's views on original sin. It offers a brief orientation to discourse on sin in the context of theological debates on human evolution. This is followed by a thick description of Haught's so-called note on original sin. A series of five observations and questions regarding Haught's position is offered. It is observed that Haught's way of telling the story of sin and salvation follows a classic Roman Catholic plot, namely one based on grace elevating nature. This is contrasted with the more typically reformed plot of restoration.

\section{Orientation: Discourse on sin in the context of science and theology}

In discourse on science and theology there is a growing corpus of literature in which biological and paleontological evidence on early human evolution is juxtaposed with Christian views on (original) sin. ${ }^{1}$ Such contributions are typically situated within the broader context of debates on the relationship between what is called 'natural evil' and 'moral evil'. ${ }^{2}$ It would be impossible to offer a review of such literature here.

In science and theology discourse on sin there is more or less consensus that the biblical portrayal of a primordial paradise followed by the 'fall' of humanity is not plausible as a more or less accurate description of early human history, given what we know from the history of the evolution of life on Earth and from hominid evolution. There is also consensus that the biblical narratives on creation and the fall should not be interpreted in a quasi-historical way but as mythic renderings of what went wrong in human history. This assertion is supported by ample biblical scholarship suggesting that the biblical texts should not be read as a quasiscientific textbook but as often polemic writings that emerged within particular historic contexts. Accordingly, the Bible and biology speak radically different languages that should not become confused and conflated. However, are these languages really totally unrelated (see Rolston 1994:207)?

Such consensus does not by itself resolve the theological task of making sense of the fall of humanity. Many scholars have noted that the metaphor of the fall is derived from early Christian literature: the metaphor itself is not found in the biblical texts and certainly not in Genesis 3, for which the term is most often used. Be that as it may, one would still need to address the question as to what went wrong in evolutionary history and how what Christians redescribe as 'sin' came to be so pervasive. Many theologians would dismiss speculations about the origin of $\sin$ - for important theological and spiritual reasons. To offer an explanation of the origin of sin typically serves the purpose of offering an excuse and exculpating humans from blame. If humans are not to be blamed, then the responsibility for sin may well lie with the Creator. This would prompt a discussion of the theodicy problem - which elicits considerable interest in discourse on theology and the sciences. However, even if the origins of sin cannot be located, one may still speak of the inception and subsequent extension of $\sin$. There is clear biblical evidence in support of such a theological interest.

In discourse on science and theology there is nevertheless considerable interest in the early emergence of $\sin$. There is some confusion as to the appropriate theological rubric under which this debate should be located. Many conflate discourse on the origin and transmission of sin with the problem of original sin (which also addresses the universal spread and inescapability of sin).

1.See, for example, Chapman (2004), Domning and Hellwig (2006), Hefner (1993:123-142), Peters (1994:294-327), Peterson (20004), Southgate (2008:28-35), Van den Brink (2011) and Williams (2001).

2.See especially Drees (2003); Du Toit (2006); and Murphy, Russell and Stoeger (2007).

Note: This work is based on research supported in part by the National Research Foundation of South Africa (grant-specific unique reference number 85944). As the grant holder, I acknowledge that the opinions, findings, and conclusions or recommendations expressed in any publication generated by NRF-supported research are those of the author and that the NRF accepts no liability whatsoever in this regard. I also acknowledge support from the Stellenbosch Institute for Advanced Studies (STIAS) where I worked as a fellow in 2015.

This article forms part of the special collection on 'Engaging development: Contributions to a critical theological and religious debate' in HTS Teologiese Studies/Theological Studies Volume 72, Issue 4, 2016. 
Others focus on the plausibility and historicity of the fall of humanity (see Van den Brink 2011). Some go further in seeking to locate the origins of $\sin$ in the human genome, often with reference to the 'selfishness' of genes (or 'original selfishness' - Domning \& Hellwig 2006), or in human instincts and emotions. There is a strange irony here in the sense that few theologians would still defend the biological transmission of sin, whereas many biologists are interested in the genetic transmission of behavioural traits (Peters 1994:327). Most express interest in the interplay between conflict (the survival of the fittest) and the need for cooperation in evolutionary history and explore the continuity and discontinuity of that interplay with regard to the ethos and structures of early human societies.

In this contribution I engage quite narrowly with the views on original sin of the American Catholic and process theologian John Haught. Haught is a major scholar who has engaged with evolutionary biology quite extensively and affirmatively, typically in the context of an evolutionary cosmology. This is evident from titles such as The Promise of Nature: Ecology and Cosmic Purpose (1993), Science and religion: From conflict to conversation (1995), God after Darwin: A Theology of Evolution (2000), Responses to 101 Questions on God and Evolution (2001), Deeper than Darwin: The Prospect for Religion in the Age of Evolution (2003), Is Nature Enough? Meaning and Truth in the Age of Science (2006), Making Sense of Evolution: Darwin, God, and the Drama of Life (2010) and, most recently, Resting on the Future: Catholic Theology for an Unfinished Universe (2015), from a range of publishers. There are, understandably, several common themes and a reworking of the same insights, including the ontological priority of the future; the story character of an unfinished universe; the evolutionary tendency towards increasing diversity, complexity and beauty; divine kenosis and a cosmic sense of purpose (but not design). The rhetoric is consistently aimed at the need for Christians (Catholic) to affirm the findings of evolutionary biology, for scientists to recognise the inherent promise of nature in order to counter what Haught describes as 'cosmic pessimism', and to elicit hope in order to resist environmental destruction.

Haught has not written extensively on original sin, although what he has written is consistent with his theological reflections on evolution in general. This may be helpful in order to contain the discussion. He has also contributed to Christian ecotheology and has expressed deep concern over the current direction of cultural evolution. I have used his typology of approaches to ecotheology elsewhere extensively (see Conradie 2006, 2011) and have welcomed his proposal of the need for an eschatological orientation for Christian Earthkeeping (see Conradie 2005; Haught 1993).

I need to note that Haught's views on original sin are deeply influenced by Roman Catholic theology in general, by the vision of Teilhard de Chardin and by process categories. By contrast, my theological intuitions are influenced by reformed theology of Dutch origin, with specific reference to the work of Herman Bavinck, Gerrit Berkouwer and Arnold van Ruler. These schools of thought are rather far apart, so that almost every aspect of the Christian faith comes into play if a comparison is to be made. Haught is therefore for me a welcome challenge as a conversation partner who may help me to clarify my own views and to contrast the strengths and weaknesses of a theology of elevation with a theology of restoration.

\section{Haught's note on original sin: A thick description}

In God after Darwin Haught included a short section entitled 'A Note on Original Sin' (2000:137-143). ${ }^{3}$ He observes that he regards this theme as far less important than the question of how to think about God in a neo-Darwinian context. He adds that his views on original sin can only be understood in terms of his outline of cosmic evolution towards increasing diversification, complexity and beauty.

Haught (2000) starts his discussion with a critique of any literal or quasi-historic reading of the biblical narratives:

Obviously an evolutionary understanding of life cannot be reconciled in a literal sense with the story of a primordial couple, Adam and Eve, rebelling against God in the Garden of Eden and passing down the consequences of their disobedience through our genetic history. The science of evolution cannot and should not be made to conform literally to the mythic biblical accounts and vice versa. (p. 137)

Haught then proceeds to offer a description of original sin in terms of the aesthetic-evolutionary vision that he develops throughout his book (see below) and indeed his oeuvre. He states:

... original sin means that each of us is born into a still unfinished, imperfect universe where there already exist strong pressures many of them inherited culturally over many generations - for us to acquiesce in an indifference to God's creative cosmic aim of maximising beauty. (Haught 2000:138)

Original sin is therefore a form of contamination 'in which the banality and ugliness of evil are tolerated so easily' (2000:139). It is 'the brokenness of the world into which each of us is born, a condition to which we humans have contributed throughout our history' (Haught 2015:40).

In this view there has never been an age of innocence or a 'fall' (a misleading metaphor) but one may identify a failure to reach the ultimate goal of increasing diversity, complexity and beauty. There may at best be, in Hegelian terms, a fall 'upwards'. We are born into a still-evolving, imperfect universe. Our folly lies in being indifferent to God's creative cosmic aim of maximising beauty. Sin is a failure of expectation - expecting too little from the God-given promise of nature. Things went wrong through the emergence of some violent forms of culture so that human beings have to be redirected to what has been the original goal. Original sin is therefore best understood as an estrangement, not from a primordial paradise that we now need to have restored, but from the ultimate purpose of cosmic evolution.

3.Subsequent references in parenthesis are to Haught's book God after Darwin (2000). 
Haught then employs the classic distinction between original sin and actual sin to explain what such an 'indifference' entails. On the one hand such indifference may lead us to actively destroy that which is good and beautiful, reducing it to disorder and chaos (e.g. through violence, ecological recklessness, disease, predation and death). This is called the 'evil of discord'. On the other hand this indifference may also lead us to tolerate unnecessary forms of monotony when creativity and beauty are called for (e.g. by imposing rigid and oppressive forms of order, including ecclesial order, but also distinctions in terms of class and caste, on minorities, women, children or the unemployed). This is called the 'evil of monotony' (2000:138). These two are dialectically related: the evil of monotony is devised to prevent chaos but often prompts discord (2000:139).

Haught carefully distinguishes actual sin from the instincts of aggression and selfishness that we may have inherited from our evolutionary ancestry. Original sin entails a distortion of such instincts towards a culturally transmitted and inherited violence and injustice that distorts and (threatens to) corrupt each of us born into this world (2000:139). In Haught's view, sin is therefore not a necessary dimension of cosmic and biological evolution, although the emergence of evil is still more or less inevitable. ${ }^{4}$ At times, though, Haught does come quite close to explaining human sin in terms of the incompleteness of an unperfected universe. $^{5}$

An awareness of such distortion, Haught continues, can occur only when we have some sense of what the world could be like. One needs a sense of the direction in which cosmic evolution is moving, namely (following Teilhard and process thinking) towards a maximising of diversity, complexity and beauty. The vision of paradise is therefore not a description of a world from the perspective of a remote mythic past that has been lost and needs to be restored, but offers a symbolic portrayal of a vision for the future 'up ahead' (2000:139). This is in line with Haught's proposal for a metaphysics of the future in which the future has an ontological priority over the present: possibility is more than essence. Accordingly, the notion of original sin expresses an estrangement from a future ideal, not from a nostalgic primordial past to which we may hope to return (2000:140). Sin entails a falling away from a promise, not from paradise. In this way, Haught claims, original sin is not only completely compatible with evolutionary science but also renders significance to cosmic evolution through a sense of purpose and promise (2000:140). We do not live in a world that was instantaneously created with an original state of perfection,

4.The distinction between sin as not being necessary but still inevitable is derived from Reinhold Niebuhr (see 1941:150). See also Tillich (1957:43-44).

5.See for example the following formulation: 'Consequently, the fundamental fault that calls for redemption and new creation is the inevitable incompleteness of our still emerging universe. The existence of both suffering and human sin are closely related to the fact that the universe is now unperfected. ... Logically speaking, an unperfected universe, since it is still in process, would inevitably have a dark side in which evil, including human sin, can presently find a foothold. The importance of evolutionary science and cosmology to Catholic theology, therefore, is that by extending the original fault to the entire cosmos, it serves to magnify the scope and healing significance of Christ's redemption so as to include the whole universe and its future' (Haught 2015:40). but in an unfinished universe in which we are continuously surprised by its beauty and novelty. This offers significance to every moment in the dynamic of evolutionary history.

Haught adds that there is then no need to identify culprits to explain how things got messed up or to bring sacrifices to restore an original integrity that was lost (2000:141). He criticises the compulsive obsession to identify and redress the origin of evil and to make 'repetitive acts of reparation for our alleged complicity in spoiling what we have taken to be an initial perfection' (2000:141). The need for expiation through punishment and reparation in order to re-establish stability and order is over, following Christ's kenotic sacrifice on behalf of all. Evolutionary science, he bluntly states, has rendered the assumption of an original cosmic perfection obsolete and implausible. We do not need to measure our world against a putative original perfection. Instead, the Christian faith invites us to consider the promise of a new creation in an evolving, unfinished world that is open towards the future. Haught (2000) captures this vision as follows:

Genuine hope for the future can survive only in a universe that forbids perpetually repeated reparations for the loss of a timeless primordial perfection. Perfection, evolution helps us to see, lies in the eschatological future, not in the indefinite temporal past, nor in an eternal present immune to the travails of becoming ... Whereas in a pre-evolutionary world the transient beauty and bliss we experience could easily be disheartening reminders of what could have been, in an evolving - and therefore unfinished - universe, they are joyful harbingers of new and unprecedented epochs of creation yet to come. Nature is essentially promise. (p. 142)

Haught concludes that thinking about original sin need not be dominated by a nostalgia for what has been lost, but by an anticipation of what might be, not by a longing to restore but by a 'creative contribution to the birth of something truly new' (2000:142). The doctrine of original sin thus points to the realisation that we are born into a world 'where the accumulated effects of despair and sin have diminished and destroyed what is good and have restricted what is possible' (2000:143). However, if the world is still very much in the making, we may be guided back to a vision of increasing diversity, complexity and beauty. Then history may be regarded as an adventure towards fresh and more profound forms of beauty. The aesthetic perspective is important to overcome a narrow ethical outlook; a vision for an attractive future, endowed with a sense of cosmic purpose, at the same time provides the source of inspiration for doing what is right in the present (see 2000:130-131).

\section{In conversation with John Haught: Some observations, questions and reservations}

As indicated above, Haught's position on original sin is compatible with the main thrust of his well-developed position. A discussion of his position on original sin therefore prompts reflection on almost every aspect of his thought. In this section I raise a series of five questions for the sake of conversation. 


\section{A warranted optimism?}

Haught's position on the promise of nature is developed polemically over and against the form of reductionism, determinism and 'cosmic pessimism' that he finds in discourse by well-known scientists on the ultimate meaning of the evolution of life. He clearly accepts and embraces the main findings from neo-Darwinian evolutionary biology but offers a rather different interpretation compared to some of its dominant exponents. He argues that such scientists unwittingly adopt metaphysical positions that extend beyond their scholarly competence so that there is room for debate. He subverts the assumption that evolutionary biology cannot be separated from a materialist metaphysics and rightly insists that biology by itself does not and cannot offer ultimate explanations without moving outside its own disciplinary boundaries (Haught 2003:92). He therefore rejects a fusion of biological and ultimate forms of explanation and pleads for metaphysical patience (Haught 2003:93).

In response Haught, drawing mainly on Teilhard and Whitehead, seeks to offer a metaphysical explanation of the very possibility of evolution within a dynamic universe although it is not always clear whether he is concerned with understanding evolution, redescribing evolution in religious terminology or fitting evolution into an existing theological framework (see Helm 2005:35). Haught is aware of the theological and philosophical pitfalls related to attempts to extract meaning from the process of evolution but insists that there is only one thing that is worse, namely not doing that since others are doing that anyway and with reductionist implications (see Haught 2005b:62).

Instead of the dominant emphasis on the 'blindness' of evolution (emphasised by Daniel Dennett and others), devoid of any sense of direction or purpose, he sees an overall historical pattern (but not a design) towards increasing diversity, complexity and beauty. As Haught insists, '[w]ithout too much difficulty, we can make out a kind of story line along which nature has traveled from trivial to more intricate and eventually sentient, conscious, and self-conscious states of being' (2000:117). He regards the obvious directionality visible in the overall movement of the cosmos from simplicity to complexity (based on the packaging of information, the integration of particulars into coherent wholes; 2000:75) as a validation to look for signs of promise in all things. He seeks to understand why novel forms of being tend to emerge in evolutionary history (2000:101). Although the propensity towards increasing complexity is obvious, there remains a debate on whether evolution permits the emergence of new forms of complexity or whether it actually necessitates such complexity.

Haught is clearly influenced here by the writings of Alfred North Whitehead and Teilhard de Chardin. For Haught this suggests that nature is seeded with promise (2000:115), is pregnant with the potential blossoming of new life (2000:118), that the future has an ontological priority over the past, that we are pulled forward by the future and not so much pushed from behind by the past and that we are therefore warranted in anticipating further novel developments in evolutionary history. He wishes to accommodate both the vision of biblical hope and the unfinished universe portrayed by contemporary science (2015:22). Following Teilhard (but also Karl Rahner, Jürgen Moltmann, Wolfhart Pannenberg and Ted Peters), Haught recommends a 'metaphysics of the future' rather than a deterministic (and materialist) metaphysics of the past, or of the eternal present, one where nature's becoming is emphasised rather than its essential being (2000:84-85). The constantly arriving and renewing future 'at the green edge of each moment' (2000:91) allows for and yields the formation of novelty that is so evident in history. Haught (2003:166) explains: 'Both the Platonic metaphysics of eternity, in which everything important has already happened, and the modern materialist ideology that explains everything "new" as simply the outcome of a past sequence of deterministic causes, can have the effect of stifling hope and depleting human energy'. Only a universe in which the truly new can occur will allow for hope in the future.

This power of the future is for Haught the 'ultimate metaphysical explanation of evolution' (2000:90). Evolution does not provide us with reminiscences of a lost past or with an impersonal unfolding of a mathematic simplicity that first appeared in the distant past but the promise of things to come (2000:95). The world is still coming into being (2003:162). Moreover, there abides in the depths of the universe 'a forever fresh wellspring of novelty' to which the word 'God' most appropriately refers (2000:9). Faith is to be grasped by that which is to come (2000:89). It is God's lure towards the future that renders nature's evolution to be God's creation (Peters 2010:935). For Haught, the dynamism of evolution corresponds with the role of human hope, a theme that permeates his oeuvre. He says: 'Hoping is the human form of groping, the way in which our species joins in with the whole history of striving that we call life. Failure to hope is, in effect, to depart from the stream of life' (Haught 2005a:13). Given this tendentious 'promise of nature' the destruction of life is a cause of grave concern but the promise of nature is also a source of inspiration to resist such destruction. This is Haught's version of an eschatological approach to Christian ecotheology (2000:145-155).

There can be no doubt about the lure of Haught's position. However, his position remains vulnerable on one crucial point, namely the ways in which the emergence of complexity is only possible within the parameters of the laws of nature that apply at a lower level of complexity. Top-down causation becomes possible through the emergence of complexity, but this cannot and does not undo the laws of gravity and thermodynamics. The emergence of life on Earth allows for increasing diversity and complexity and this may indeed yield further surprises, but this process will not continue indefinitely, given the finite existence of the Earth itself and the solar system. Haught's sense of optimism therefore does not seem warranted, short of some future divine intervention which Haught's own position rightly does not allow. Yet his formulations in this regard often remain ambiguous, leaving some room for some or other different outcome. For example, in his Boyle Lecture Haught states: 
That the story of the Big Bang universe will itself eventually come to a physical end - freeze or fry - should not be disturbing to those who trust in God's promise of redemption. An infinitely compassionate and resourceful Future can be the ultimate redemptive repository of the entire series of cosmic occurrences no less than of those episodes that make up our individual lives. (Haught 2005a:20)

Haught's emphasis on the directionality of evolution (see also 2010:67-85) is perhaps appropriate (although contested; see Berry 2005:51), but whether a sense of purpose can be derived from that (even retrospectively) remains debatable. Evolutionary biologists (with notable exceptions such as E.O. Wilson) have been very wary of portraying evolution as biological progress and have been highly sceptical of Teilhard's endorsement of such progress (Ruse 2012:112). Berry (2005:52) worries that Haught's emphasis on directionality creates the impression that evolutionary science implies an inevitable and nonmaterial progression. This will yield a facile religious optimism that is ineffective against ideological distortion. Moreover, as Peters (2010:928) observes, a remnant of the liberal confidence in progress surfaces in Haught's work: in place of complexity he puts beauty. Moreover, any notion of evolutionary progress is thwarted precisely by a recognition of the impact of human sin: 'Even if the theistic evolutionist finds it difficult to reaffirm the historicity of an Adamic fall, the constancy of human sin and the tragedy of human suffering pop the balloons of naive doctrines of ascending progress' (Peters 2010:928). Instead of seeking some purpose inherent in nature itself, Peters suggests that one may identify a divine purpose for nature (Peters 2010:929). The underlying question is whether the progression of evolution towards increasing complexity can be sustained eschatologically.

\section{Kenosis as cosmic principle?}

For Haught the inverse of an evolutionary process towards increasing diversity, complexity and beauty is a kenotic principle at work throughout cosmic history. The death of stars is necessary for the formation of heavier elements and planets. Life on Earth can only evolve if predation, degeneration, pain, suffering and death are built into the process. The same applies to the evolution of species, which requires considerable experimentation, many dead ends, incredible wastefulness and the extinction of some species to allow niches for others to fill. Haught is deeply aware of the challenge posed by the recognition that struggle, pain, suffering, cruelty, brutality and death are embedded in nature (2000:20-22). He agrees that Darwin has given unprecedented breadth to our sense of the tragic (2000:22). He regards the limitations, frustrations, challenges, suffering and perishing embedded in evolutionary history as tragic features of existence that are necessary conditions for the emergence of creativity, affection and beauty. Our ethical aspirations therefore need not be regarded as an extrapolation of selfish, self-replicating genes but as a carrying forward, at the human level, of the universe's own propensity towards and intensification of complexity, diversity and beauty (2000:132).
For Haught, this evolutionary process is enfolded in a narrative of God's vulnerable and therefore creative love. God's power is best understood in terms of persuasive love rather than as a coercive force (2000:41). This is a God who does not impose a rigid and sterile order through intelligent design but who is willing to risk the disorder that occurs in the evolution of cosmic beauty through a creative 'letting be' of creatures (2000:40,137), lovingly allowing them to be something radically other than divine (2000:56), endowing the world with a surprising degree of autonomy (2000:119). This offers a portrait of a self-giving rather than a selfaggrandising mystery (2000:47). An unrestrained display of infinite presence would leave no room for anything other than God and would rule out evolutionary selftranscendence (2000:112). This recognition of a kenotic principle at work in nature is Darwin's gift to theology (2000:45-56) - to allow for a rediscovery of God's selfemptying love and vulnerability, exemplified in the cross of Jesus Christ. Haught says: 'In the symbol of the cross, Christian belief discovers a God who participates fully in the world's struggle and pain' (2000:46). The Creator's power is made manifest in the vulnerable defencelessness of a crucified man (2000:113). This stands against an emphasis on God's ultimate power and sovereignty - which is alienating, raises intractable theodicy problems and is not compatible with evolutionary biology. Inversely, a kenotic notion of God may help to understand the direction and ultimate purpose of evolution.

Haught's emphasis on kenosis is clearly attractive and is shared by numerous contemporary scholars, including George Ellis, Jürgen Moltmann, Arthur Peacocke and John Polkinghorne (see especially Polkinghorne 2001, also Ellis \& Murphy 1996), to mention only a few with whom Haught aligns himself. In my view there remains a question mark about treating kenosis as a universal, cosmic principle. This would seem to undermine the contingent and historical nature of specific acts of kenosis. One may argue that specific acts of kenosis exemplify the underlying principle and can be discerned only retrospectively, but biblical proclamation seems to suggest that the cross of Christ is God's radically contingent, unexpected response to address and overcome human sin. Does an emphasis on a cosmic principle not undermine the dynamism of history that Haught wishes to emphasise? Does he not subsume God's work of salvation under God's work of (ongoing) creation? How is God's kenotic presence in the suffering of creatures redemptive? Does Haught's notion of kenosis not risk affirming a divine 'acceptance' of the world's suffering (see Peters 2010:931)? Moreover, the notion of kenosis can also serve to subtly endorse suffering in nature instead of offering the moral incentive to address or at least alleviate such suffering. The message of a God who is totally involved in creation but powerless to overcome suffering may not be all that liberative (see Deane-Drummond 2006:172). Admittedly, Haught (2003:82) recognises the danger of speaking of a powerless God incapable of redeeming a flawed creation. 


\section{Cur deus homo?}

Haught aligns himself with a Scotist rather than a Thomist understanding of the incarnation. In response to the classic question Cur deus homo? , Haught believes that the incarnation of Christ would have taken place in any case, irrespective of $\sin$. This speculative move is an important and still a typically Roman Catholic one. It assumes that the plot of the drama of God's work revolves around the tension between nature and grace. It places the incarnation within the wider compass of cosmic history to suggest that the incarnation is an exemplary instantiation of the divine kenosis. It is a proleptic anticipation of the telos of evolution. It illustrates that increasing diversity, complexity and beauty can be attained only through pain, death and sacrifice. For Haught (2005a:11), 'this is the best of all possible worlds, after all, and divine providence is manifest in the rigour as well as the creativity of evolution'.

Nature (evolutionary history) requires redemption irrespective of human sin, which has only exacerbated the suffering that was already present. For Haught (2015:95), the Darwinian discovery that 'most of life's suffering (and death) has nothing to do with guilt' is liberative. This discovery has delivered us from the impossible burden of fitting all suffering onto the grid of guilt and punishment (Haught 2015:99). The significance of redemption in Christ therefore has to be cosmic in scope (see Haught 2015:40).

This approach may be contrasted with one that operates within the typically Protestant contrast between sin and grace. Both sin and grace may be understood with reference to nature (and therefore also history). Sin describes the distorted direction that that which is material, bodily, earthly and human has taken, whereas grace is not material by itself (medicine) and is not added to nature but is necessary to redirect nature (and therefore history). Grace is not equated with salvation, since both creation and salvation are understood as graced. The drama is then a far narrower one, namely of God's response within one episode of history to the destructive impact of human sin.

The question here is which of these two narratives is better able to do justice to that which is material, bodily and earthly. The danger with Haught's position is that grace may be regarded as a supplement to nature because nature (the body) is regarded as too prone to suffering and not only because the process of evolution remains incomplete.

\section{Salvation as elevation?}

For Haught, salvation in Jesus Christ is best understood as a form of elevation and not as restoration. The evolutionary trajectory, he believes, is a movement towards increasing diversity, complexity and beauty. This is a movement that is graced by God's permeating presence. Grace does not abolish nature but perfects it. Such grace is able to overcome the distortions, dead ends and wastefulness of evolution. On that basis it also allows for the birth of new life and new species amidst episodes of destruction and catastrophe. The evolution of sin may be regarded as one such episode, but this is placed in the much wider compass of cosmic evolution. One may say that, for Haught, nature (and history) is able to redeem itself. This is because it is permeated by God's presence (understood in terms of process categories as a dipolar reality) or in terms of Teilhard's notion of a 'divine milieu'.

Haught therefore rejects a notion of salvation as restoration. The very idea of a fall from primordial innocence elicits a spirituality of restoration rather than renewal (Haught 2015:26). He rejects a focus on expiation since it (seems to) assume a notion of original perfection or at least harmony that needs to be restored (Haught 2015:91). The main problem is not merely one of getting rid of a stain. It is clear that the meaning of the prefix 're' is problematic. What is it that needs to be restored? From an evolutionary perspective it cannot imply the restoration of a primordial paradise. This would suggest a static universe and would not allow for the flow of time. Haught (2003:170) adds: 'although the re-storation may be garnished at its margins with epicycles of novelty, it will be essentially a re-establishment of the assumed fullness that once was and now has dissolved'. Moreover, such a notion of restoration does not elicit the inspiration needed to address what is wrong in the world.

If we assume, along with most classical Christian theology, an initial human fall from a primordial integrity, then pursuit of the ethical life would perhaps be motivated by a sense of shame at our rebellion against God, by the need to restore through expiation the primordial perfection that had been defiled, or more nobly, by a commitment to do good simply for the sake of the good. Heroic though it may be, however, the practice of virtue in that case has little to do with contributing cooperatively with God to the creation of something new. (Haught 2015:18)

By contrast, an evolving universe is not yet finished; it may aim towards perfection but cannot ever be perfect (2000:55). It is impossible to return to a previous dispensation - as much as it is impossible for an adult to recover a lost childhood. How, then, can one know what it is that has to be restored? Most of the problems related to theologies of restoration emerge from a speculative reconstruction of what God has created, which is then used as a point of departure for what salvation is supposed to entail. Such a focus on the original 'orders of creation' has often been disastrous, for example in debates on ethnicity (apartheid) and homosexuality. The meaning cannot be that 'creation' is restored, as this would suggest an ahistorical, non-evolutionary notion of creation. It can scarcely entail a return to the beginning or to some previous state or earlier phase. What is restored is not that which is material, bodily and earthly, as such, but something about that which is material, bodily and earthly. What that 'something' is remains open to dispute: it can be understood as a return to its evolutionary potential; to its full fruitfulness, its ability to flourish; to a sense of orientation; to the original goal; to its relatedness with God; to a reciprocal covenant relationship with God; and so forth. In short, the problem with a theology of restoration is that it can scarcely do justice to evolutionary history. The question, though, is whether the 
notion of elevation does not all too easily degenerate towards a subtle rejection of the inadequacies of bodily and earthly existence. If so, elevation would mean that we have to be redeemed from the suffering embedded in nature and in that sense from nature itself. 'Redemption, if it means anything at all', Haught (2003:169) insists, 'must mean - perhaps above everything else - the healing of the tragedy (and not just the consequences of human sin) that accompanies a universe in via'. Indeed, '[e]specially in view of Darwin's portrait of the life-story, one through which we can now survey previously unknown epochs of life's tragic suffering and struggle preceding our own emergence, it would be callous indeed on the part of theologians to perpetuate the one-sidedly anthropocentric and retributive notions of pain and redemption that used to fit so comfortably into preevolutionary pictures of the world' (Haught 2003:169). And elsewhere: 'Redemption must mean, then, at the very least, that the whole story of the universe and life streams into the everlasting bosom of divine compassion' (Haught 2005a:17). Or more recently: 'Redemption must signify the healing not only of the evil caused by human guilt but also of the cosmic fault coexistent with the fact of an unfinished universe' (Haught 2015:92). In an important formulation Haught (2003) concludes:

In an unfinished universe, we humans remain accomplices of evil, of course-even horrendous forms of evil. But our complicity in evil may now be interpreted less in terms of a hypothesised break from primordial innocence than as our systematic refusal to participate in the ongoing creation of the world. The creative process is one in which the multiple, the originally dispersed elements of an emerging cosmos, are now being drawn toward unity. Our own sin, then, is at least in some measure that of spurning the invitation to participate in the holy adventure of the universe's being drawn toward the future (the God-Omega) upon which it leans as its foundation. Here sin means our acquiescence in and fascination with the lure of the multiple. It is our resistance to the call of 'being more', our deliberate turning away from participation in what is still coming into being. (p. 175)

One needs to ask whether soteriological motifs such as liberation from oppression or reconciliation amidst violent conflict can be accommodated in terms of Haught's understanding of salvation. Is creation (or creativity) not being equated here with salvation? ${ }^{6}$

\section{Cosmic remembrance?}

As indicated above, Haught sees evolutionary history as a movement towards increasing diversity, complexity and beauty. This gives every moment in history a certain significance. The emphasis on the future allows for a critique and destabilising of current constellations of power. Indeed:

[r]eligious infatuation with the past or romantic nostalgia for an ahistorical eternal present ... can allow us all too easily to legitimate the miserable circumstances of the afflicted and thus close us off to the future that their own suffering opens up. (Haught 2000:98)

6.I discuss the tendency to regard salvation as creative and creation as salvific at som length in The Earth in God's Economy (Conradie 2015). I argue that neither a fusion nor a compartmentalising of these aspects of God's work is feasible.
The power of the future is sensed most palpably by the poor and oppressed (Haught 2000:99).

However, this does raise the question whether every previous generation is not sacrificed for the sake of reaching the final goal. In human history this would imply that heroes, martyrs and saints may need to sacrifice their lives in order to build a better society. In evolutionary history this may imply that the death of species and specimens is required in order to ensure increasing diversity and complexity. ${ }^{7}$ A sacrificial justification is thus provided for the nonhuman and hominid victims of evolutionary history. The goal of the process becomes more important than the individual (Page 1996:48). One has to wonder whether what is good for the species can really compensate for the fate of any individual victim (see Southgate 2008:44-47). Does the massive emphasis on the future not undermine the appreciation and joy of being alive in this particular moment? ${ }^{8}$ Moreover, the directionality of history seems to remain rather anthropocentric given the emphasis on increasing complexity, so that the suffering of other forms of life seems to be legitimised for the sake of human and cultural evolution. This criticism plagues the Teilhardian emphasis on noogenesis so that other animals are acknowledged as part of the evolutionary process but fall short of the ultimate goal of increasing complexity.

Haught pre-empts such criticisms through an emphasis on God's loving remembrance. The whole of history has meaning because it is preserved in the mind of God. This is understood in terms of dipolar process categories as a form of objective immortality. In Haught's own formulations:

Everything whatsoever that occurs in evolution - all the suffering and tragedy as well as the emergence of new life and intense beauty - is 'saved' by being taken eternally into God's own feeling of the world. Even though all events and achievements in evolution are temporal and perishable, they still abide permanently within the everlasting compassion of God. (Haught 2000:43)

He adds:

A vulnerable God, as the Trinitarian nature of Christian theism requires, could not fail to feel intimately and to 'remember' everlastingly all of the sufferings, struggles and achievements in the entire story of cosmic and biological evolution. By holding these and all cosmic occurrences in the heart of the divine compassion, God redeems them from all loss and gives eternal meaning to everything .... (Haught 2000:56)

This suggests that nothing that has happened in history is gone forever. We carry the whole of evolutionary history in our genes. We exist, also in the present moment, in the mind of God, like characters in a playwright's plot who are allowed

7.Elsewhere Haught (2015:70) suggests that in a 'fully finished' and 'completely intelligible universe death does not have a legitimate place anymore. Death will be no more' (Rv. 21:4) One may agree that there will be no more dying when the story of life has ended, but the death of creatures throughout history can never be undone.

8.Schaab (2010:904) raises a similar question: 'despite Haught's statements to the contrary, it [arrival of God from the future in an evolutionary worldview] devalues
conten contrary, it [arrival of God from the future in an evolutionary worldview] devalues
the present and the past that provide the limits and potentialities on which evolution and emergence depend'. 
a degree of independence and creativity to express. Haught argues that this cosmic remembrance is compatible with the ultimate heat death of the universe. He says: 'The so-called heat death that may be awaiting the universe is not inconsistent with the notion that each moment of the entire cosmic process is taken perpetually into, and preserved everlastingly in, the boundlessly redemptive future that faith names as God' (2000:115). Even if consciousness were to eventually vanish from the Earth in the possible heat death of the universe, the fact that it shall have existed and flourished adds significant beauty to the story as a whole - that 'comes to rest eternally in the empathy of God' (2000:130). Haught's hope for 'surprising future outcomes' (2000:115) seems to be based on religious belief rather than the evolutionary pattern of increasing complexity diversity and beauty. He points rightly to indeterminacy in physical processes but uses that to answer the question of cosmic destiny (2000:116) on the basis of selected evidence for the promise of nature. Is the destiny of the cosmos located within or beyond cosmic history? He wishes to associate a natural concern for cosmic future with the biblical hope for the coming of God and the transformation of all creation in God, who is the world's ultimate goal and absolute future (2015:119), but whether this association is really warranted remains unclear. What then about the laws of thermodynamics that seem to dampen any sense of ultimate optimism? Haught (2015:126) refuses to put limits on the possible prematurely. He insists that the universe, including the laws of thermodynamics, remain open to different readings and outcomes (2003:51). He hopes that, somehow, the totality of cosmic events, including the whole history of tragic suffering, will find redemption in the eternal compassion of God (Haught 2015:120). However, is this return to the use of the category of the eternal consistent with his own emphasis on history and the future? Perhaps it is best to say (with Peters 2010:934) that the future entails a gathering together of all past and present moments so that 'future comprehensive wholes draw past particulars into new patterns of coherence'.

Process theologians such as Haught have often been criticised for this form of eschatology. It may appear as if God is regarded as an omniscient super-computer who remembers everything in order to resolve the problem of mortality and transience ('perpetual perishing'). The kenotic emphasis on God's vulnerability is then eschatologically reversed with an emphasis on God's omniscience and therefore omnipotence. Haught (2010:104) says: 'Deeper than evolution, beneath all becoming, perishing, and death, Christians believe, there abides an eternal repository that retains with full immediacy every event that ever happens, including the whole drama of life'. However, a God who remembers everything would imply that all the evils of history are preserved in this way as well. This is, in fact, a harrowing image of hell. Something more than a compassionate remembrance is required. What is needed is a loving transformation of what went wrong in history, the hope for divine judgement to put things right, for justice to the past, present and future victims of history, a radically new dispensation inaugurated by the symbol of resurrection, a sense of cosmic reconciliation. Perhaps the past is the locus of sin, the future the locus of grace and the present the time for decision-making. Haught does address the theme of resurrection as something bodily and suggests that this may be understood in terms of a transition from a limited and particular connectedness with nature to an even deeper pancosmic intimacy with the whole of nature (2000:161-162). He believes that it would suffice to understand bodily resurrection in terms of our 'subjective identities to be somehow saved everlastingly along with the cosmic drama by the Spirit of God in communion with the risen Christ' (Haught 2015:126).

Given categories, such as eternal and communion (presence!) with God, the kenotic pattern in Haught's theology is apparently not sustained eschatologically.

\section{Conclusion}

The observations above may be expressed in one integrated question: How is John Haught telling the story of God's work of creation, salvation and consummation? One may say that the plot of this theologically reconstructed narrative normally revolves around the predicament of sin. How does God's work of creation, salvation and consummation help to overcome sin and evil? For Haught, though, sin itself is situated in the larger set of predicaments associated with finite creaturely existence in an evolving world.

The strategy that Haught employs to tell the story is a classic Roman Catholic one, namely that of salvation as elevation. Grace does not abolish nature but perfects it. Accordingly, God's work of creation is understood as a creative letting be of creatures, allowing them to evolve towards increasing diversity, complexity and beauty. In evolutionary history one may detect an underlying pattern and overall sense of purpose that follows the Teilhardian strategy of elevation from cosmogenesis via biogenesis to noogenesis. This pattern may be found despite the immense suffering embedded in evolutionary history, the many dead ends and wastefulness of the evolutionary process. Within this longer history the emergence of humanity may be understood in terms of increasing complexity, but this comes at the cost of increasing anxiety over human finitude. Sin is best understood as a collective failure to reach the desired goal - which exacerbates the underlying predicament. Sin is thus a matter of failing, not falling (Rolston 1994:222). Or as Rolston (1994:223) has it, '[h]umans are made godward, to turn toward God, but they shrink back and act like beasts'. Salvation in Christ is thus understood as redirecting (human) evolution towards its ultimate goal (increasing diversity, complexity and beauty) but also in terms of divine kenosis - which is already evident from the kenotic letting be of creatures. Such self-emptying love allows nature to flourish in anticipation of what the future may hold. Nature is pregnant with this promise. Consummation is then understood as reaching this (original) goal - so that the whole of evolutionary history can be treasured in communion with God. 
It is particularly striking that the consistent pattern of elevation towards increasing diversity, complexity and beauty is enabled by the inverse of an equally consistent divine kenosis - except that such kenosis is apparently not sustained eschatologically. As indicated above, Haught seeks to come to terms with the finitude of history itself and finds the clue in the notion of history as a whole. The whole of history is simultaneously 'present' with God. God's eternal presence is thus not defined so much in terms of endless duration but in terms of the simultaneity of transient events (see Haught 2003:152-153). How such simultaneous presence is redemptive remains unclear. One may observe that the suffering embedded in evolutionary history and the injustices of human history are juxtaposed with (and thus judged by) God's kenotic compassion but such 'objective immortality' seems to reify and does not actually overcome suffering and sin, death and destruction.

Haught's version of the story of God's work is clearly aimed at the rejection of another classic (Augustinian) version of the plot of God's work, namely in terms of the restoration of creation. Accordingly, the aim of God's work of creation is understood in terms of God's glory. Creation (understood as creatura) is judged to be 'wholly good', if perhaps not 'perfect' (the term that Haught uses consistently), but is radically distorted through the fall. The incarnation is a response to human sin (interpreted as an event in history) only and is aimed at a restoration of an ongoing yet broken relationship between the Creator and (human) creatures. Both sin and salvation have a contingent character and are aimed at allowing creatures to exist before God once again. The contrast is therefore not between nature and grace but between sin and grace: grace restores nature. Or better: grace allows evolutionary history to continue without being inhibited by sin. The narrative of God's work thus has a stepwise character with discrete actions of creation (allowing for ongoing creation), providence (as God's response to contain $\sin$ ), the history of salvation (including the formation of the church, its ministries and missions) and consummation. These aspects of God's work cannot be conflated with each other without altering the plot. The tensions between creation and fall, providence and salvation, creation and salvation, salvation and consummation have to be maintained. Consummation is then understood in terms of restoration, as the final reconciliation of all things in Christ. As indicated above, though, it is typically not clear what it is that needs to be restored and how this could be compatible with evolutionary history. ${ }^{9}$ For Haught (2000:187), if perfection has already been attained en arche, nothing substantially new can ever emerge in history. He explains:

The creation of the world is energised not so much from what has passed as from what lies ahead. If so, it is through evolution, and not in spite of it, that we, along with the whole of creation, approach the sacred arche, the origin that is also the end of all

g. Such a theology of restoration is typical of one strand of Dutch reformed theology that is a is associated with the A mes of Abraham Kuyper, Herman Bavinck, Gerrit Berkouwer and Arnold van Ruler. A stronger emphasis on a narrive that allows for elevation is found in the oeuvre of Hendrikus Berkhof (see especially 1986:156-210). He develops his position on the basis of the Swiss reformed theology of Karl Barth and explicitly in order to be compatible with an evolutionary worldview. things. In tilting towards their future, all things are filled with worth. They participate in and sacramentally mediate the sacred, not by being diminished leftovers from a primordial paradisal integrity, nor by dimly reflecting a finished eternal present, but by bearing in their present fragility and instability an Absolute Future. The beauty and value emergent in the various phases of the evolving universe are not simply epiphanies of an eternally present perfection residing outside of time but also perishable promises of what is to come. And it is in its openness to what is to come that all of the world's past receives continually fresh redemption. (Haught 2000:189)

Haught adds that a God of evolution does not fix things in advance. God's plan is less a design or a blueprint than an envisagement of what the cosmos might become:

The original source of all values does not reside primarily in the past, nor in the vertical timeless of an eternal present, but in the richer realm of new possibilities that we refer to faintly as future ... the various 'levels of being' find their respective grades of value in terms of their openness to an Absolute Future. Here religious nostalgia is transformed by hope, and pious romanticism by anticipation of the altogether unprecedented. The meaning and value of temporal existence derive from its partaking in new creation. Without the arrival of what is truly new, time would curl back into the closed circularity that has nauseated adventurous souls, turning them away from lifeless ideas of God. In our still unfinished universe, however, all beings may participate - in a finite and precarious way - in a future yet to be actualised, one that at its ultimate depths may justifiably be called 'sacred', a mysterium tremendum et fascinans. (Haught 2000:190)

These two versions of the story, based on (1) a theology of restoration or (2) a theology of elevation, cannot be reconciled easily with each other. The only available alternatives are even less attractive. These include an eschatological 'replacement' of creation by a radically new creation and a secularised narrative of 'recycling' in which nature redeems itself through the evolutionary process. ${ }^{10}$

Haught is clearly attracted to a plot based on 'elevation' because it seems to do better justice to evolutionary history. It allows for a spirituality of discovery and not only recovery (2000:190). Proponents of an (Augustinian) theology of restoration argue that such an emphasis on elevation often undervalues that which is material, earthly and bodily by emphasising the increasing complexity associated with mind, soul, spirit and the divine. Accordingly, they resist the suggestion that the telos of creaturely existence is theosis. This is the Athanasian credo: God in Christ became human so that we can become divine. One may revise this in a less anthropocentric way to say that God became a creature through 'deep incarnation' (Niels Henrik Gregersen; see 2015) so that creatures may (again?) become what they are in communion with God. However, this would imply a theology of restoration rather than elevation. Intriguingly, Irenaeus's notion of recapitulation holds together this contrast between salvation as elevation and salvation as restoration. This 10.For a discussion of these four ways of structuring the plot of the narrative of God's work, see my book The Earth in God's Economy (Conradie 2015). 
debate cuts to the core of any theological reflection on God's work but remains unresolved.

\section{Acknowledgements Competing interests}

The author declares that he has no financial or personal relationships that may have inappropriately influenced him in writing this article.

\section{References}

Berkhof, H., 1986, Christian faith: An introduction to the study of the faith, WB Eerdmans, Grand Rapids, MI.

Berry, R.J., 2005, 'The Lions Seek their Prey from God: A commentary on the Boyle Lecture', Science \& Christian Belief 17(1), 41-56.

Chapman, M., 2004, 'Hominid failings: An evolutionary basis for Sin in individuals and corporations', in P. Clayton \& J. Schloss (eds.), Evolution and ethics: Human morality in biological and religious perspective, pp. 101-113, Eerdmans, Grand morality in
Rapids, MI.

Conradie, E.M., 2005, Hope for the earth - Vistas on a new century, Wipf \& Stock, Eugene, $\mathrm{OR}$.

Conradie, E.M., 2006, Christianity and ecological theology: Resources for furthe research, Study Guides in Religion and Theology 11, SUN Press, Stellenbosch.

Conradie, E.M., 2011, Christianity and earthkeeping: In search of an inspiring vision, Resources in Religion and Theology 16. SUN Press, Stellenbosch.

Conradie, E.M., 2015, The earth in God's economy: Creation, salvation and consummation in ecological perspective, Studies in Religion and the Environment, vol. 10, LIT Verlag, Berlin.

Deane-Drummond, C.E., 2006, Christ and evolution: Wisdom and wonder, Fortress Press, Minneapolis, MN.

Domning, D.P. \& Hellwig, M.K., 2006, Original selfishness: Original Sin and evil in the light of evolution, Ashgate, Aldershot.

Drees, W.B. (ed.), 2003, Is nature ever evil? Religion, science and value, Routledge, London.

Du Toit, C.W. (ed.), 2006, Can nature be evil and evil natural? A science-and-religion view on suffering and evil, Unisa, Pretoria.

Ellis, G.F.R. \& Murphy, N., 1996, On the moral nature of the universe, Fortress Press, Minneapolis, MN

Gregersen, N.-H. (ed.), 2015, Incarnation: On the scope and depth of Christology, Fortress Press, Minneapolis, MN.

Haught, J.F., 1993, The promise of nature: Ecology and cosmic purpose, Paulist Press, Mahwah, NJ.

Haught, J.F., 1995, Science and religion: From conflict to conversation, Paulist Press, Mahwah, NJ.

Haught, J.F., 2000, God after Darwin: A theology of evolution, Westview Press, Boulder, CO.
Haught, J.F., 2001, Responses to 101 questions on God and evolution, Paulist Press, Mahwah, NJ.

Haught, J.F., 2003, Deeper than Darwin: The prospect for religion in the age of evolution, Westview Press Boulder, CO.

Haught, J.F., 2005a, 'The Boyle Lecture 2003: Darwin, design and the promise of nature', Science \& Christian Belief 17(1), 5-20.

Haught, J.F., 2005b, 'True union differentiates: A response to my critics', Science \& Christian Belief 17(1), 57-70.

Haught, J.F., 2006, Is nature enough? Meaning and truth in the age of science, Cambridge University Press, Cambridge.

Haught, J.F., 2007, Christianity and science: Toward a theology of nature, Orbis Books, Maryknoll, NY.

Haught, J.F., 2010, Making sense of evolution: Darwin, God and the Drama of Life, John Knox Press, Louisville, KY

Haught, J.F., 2015, Resting on the future: Catholic theology for an unfinished universe, Bloomsbury, New York.

Hefner, P., 1993, The human factor: Evolution, culture and religion, Fortress, Minneapolis, MN

Helm, P., 2005, 'Reflections on the Boyle Lecture', Science \& Christian Belief 17(1), 35-40.

Murphy, N., Russell, R.J. \& Stoeger, W.R. (eds.), 2007, Physics and cosmology: Scientific perspectives on the problem of natural evil, vol. 1, Vatican Observatory Publications, Vatican City.

Niebuhr, R., 1941, The nature and destiny of man: A Christian interpretation, Volume 1 Human nature, Charles Scribner's Sons, New York.

Page, R., 1996, God and the Web of creation, SCM Press, London.

Peters, T.F., 1994, Sin: Radical evil in soul and society, W.B. Eerdmans, Grand Rapids, MI.

Peters, T.T., 2010, 'Constructing a theology of evolution: Building on John Haught', Zygon 95(4), 921-937. http://dx.doi.org/10.1111/j.1467-9744.2010.01142.x

Peterson, G., 2004, 'Falling up: Evolution and original Sin', in P. Clayton \& J. Schloss (eds.), Evolution and ethics: Human morality in biological and religious perspective, pp. 273-286, W.B. Eerdmans, Grand Rapids, MI.

Polkinghorne, J. (ed.), 2001, The work of love: Creation as kenosis, W.B. Eerdmans, Grand Rapids, MI.

Rolston, H., 1994, 'Does nature need to be redeemed?', Zygon 29(2), 205-229. http:// dx.doi.org/10.1111/j.1467-9744.1994.tb00661.x

Ruse, M., 2012, The philosophy of human evolution, Cambridge University Press, Cambridge.

Schaab, G.L., 2010, 'An evolving vision of God: The theology of John F. Haught', Zygon 95(4), 897-904. http://dx.doi.org/10.1111/j.1467-9744.2010.01140.x

Southgate, C.B.S., 2008, The groaning of creation: God, evolution and the problem of evil, Westminster John Knox Press, Louisville, KY.

Tillich, P., 1957, Systematic theology Volume 2: Existence and the Christ, University of Chicago Press, Chicago, IL.

van den Brink, G., 2011, 'Should we drop the fall? On taking evil seriously', in E.A.J.G. Van der Borght \& P. Van Geest (eds.), Strangers and Pilgrims, pp. 761-777, Brill, Leiden.

Williams, P., 2001, Doing without Adam and Eve: Sociobiology and original sin Fortress Press, Minneapolis, MN 